\title{
Wildlife Tuberculosis in Southeast Asia: A Less Known Potential Hot-Spots and Issues in Disease Surveillance and Management
}

\author{
Azlan Che-Amat ${ }^{1 *}$ and Bee Lee 0ng ${ }^{2}$ \\ ${ }^{1}$ Department of Veterinary Clinical Studies, University Putra Malaysia (UPM), Malaysia
}

${ }^{2}$ Faculty of Veterinary Medicine, University Malaysia Kelantan (UMK), Malaysia

Submission: April 05, 2018; Published: May 24, 2018

*Corresponding author: Azlan Che-Amat, Department of Veterinary Clinical Studies, Faculty of Veterinary Medicine, University Putra Malaysia (UPM), 43400 Serdang, Selangor, Malaysia, Tel: +603 8609 3923; Email: c_azlan@upm.edu.my

\begin{abstract}
Wildlife tuberculosis is a threat to the domestic livestock, other wildlife species and human, which may cause an impact to economy, wildlife conservation and serious public health issues. Increasing trend in detection of wildlife tuberculosis reservoir has hindered the progress of controlling this disease. South East Asia is known for her biodiversity hot spots in the world, with high species richness including abundance potential wildlife tuberculosis reservoirs such as wild boar and multi species of deer. Furthermore, one-third of the world's human tuberculosis is found in the South East Asia. With very little information of livestock and wildlife tuberculosis and potential hot-spot region, attention should be given by the researcher, policy makers and various stakeholders to assess the disease threat and the impact on tuberculosis control in livestock in South East Asia. South East Asia countries also face issues and limitation in conducting tuberculosis surveillance and detection. Such limitations may be overcome by collaboration and networking with expertises under One Health alliance by outsourcing the capabilities of funding, human and laboratory resources and knowledge. This paper gives an overview of potential wildlife tuberculosis occurrence in South East Asia due to her wildlife biodiversity which could potentially act as a reservoir for domestic livestock at the wildlife interface, and discuss the challenges and benefits that could arise from the global experience and resources.
\end{abstract}

Keywords: Wildlife tuberculosis domestic livestock; Wildlife reservoir; Wildlife species diversity; South East Asia; Disease surveillance; Wildlife reservoirs; Mycobacterium bovis; Geographical; Domestic cattle; Livestock; Encroachment; Goats; Cattle; Buffaloes; Asian elephant; Eradication; Indian races.

Abbreviations: TB: Tuberculosis; MTC: Mycobacterium tuberculosis Complex; NHP: Non-Human Primates; WAHID: World Animal Health Information Database; EPT: Emerging Pandemic Programme; USAID: U.S. Agency for International Development.

\section{Introduction}

In recent decades, many Mycobacterium bovis (M. bovis) infection causing tuberculosis (TB) has been detected in wildlife reservoirs, restricting the progress in eradicating the disease especially from cattle [1]. Across the world, several evidences had shown severe problems associated with wildlife reservoirs of bovine tuberculosis, involving different host species in different geographical conditions. These include popularly known wildlife reservoir for M. bovis in United Kingdom, i.e., the European badger (Meles meles) causing spill over to domestic cattle [2,3]; brushtail possum (Trichosurus vulpecula) in New Zealand causing spread to cattle, deer and ferrets [4-7]; African buffaloes (Syncerus caffer) in South Africa which spill over to other wild animals [8,9]; cervids including white-tailed deer (Odoicoileus virginianus) and elk (Cervus canadensis) in North America and Canada [10-12] and red deer (Cervus elaphus)
$[13,14]$ and Eurasian wild boar (Sus scrofa) in Spain causing spill over to livestock animals (cattle, goats, pigs), deer and wild animals such as in Iberian lynx [14-17]. Human encroachment of the natural environment by agricultural expansion and supplemental feeding to wildlife may introduce the causative agent of bovine tuberculosis at the interface of domestic cattle and wildlife species leading to development of tuberculosis in wildlife reservoir [1].

From 25 recognized biodiversity hot spots in the world, seven are in Asia which covers the entire ASEAN region. South East Asia (SEA) contains the highest mean proportion of country-endemic bird (9\%) and mammal species (11\%) compared to the other tropical regions and has the highest mammal species diversity in Asia. The high species richness and endemism in SEA is linked to its complex geographical history $[18,19]$. Around $33 \%$ of the 
world's human tuberculosis or about 4.9 million cases are found in the SEA with more than 2 million human diagnosed annually by national TB programmes [20]. The most widely recognized aetiology causing human TB is Mycobacterium tuberculosis ( $M$. tuberculosis), yet an obscure proportion of cases are due to $M$. bovis [21]. In most SEA countries, though bovine TB is notifiable, there is no proper eradication and control programme for this disease. To date, human tuberculosis remains a major public health concern and alarming due to increasing in prevalence of multidrug-resistant tuberculosis worldwide [22].

This non-systematic review attempts to give an overview on Mycobacterium tuberculosis complex (MTC) causing wildlife tuberculosis in SEA, a less known status region with a potential disease occurrence based on their bio diversified wildlife population which could potentially act as a reservoir for domestic livestock at the wildlife interface. We also discussed the challenges that might be faced by the SEA countries in surveillance programme and the benefits that could derive from the global experience and resources.

\section{An Overview of TB in Livestock and Wildlife in SEA from the Data Year 2005-2013}

From the data of World Animal Health Information Database (WAHID) Interface of World Animal Health Organization (OIE) [23], the incidence of bovine and wildlife TB is low in Malaysia, Thailand, Myanmar and a few unverified cases in Vietnam. These include domestic goats, cattle, buffaloes, Asian elephant and few unknown wildlife species. Figure 1 demonstrated a less characterized geographical circumstance of bovine and wildlife tuberculosis in SEA region.

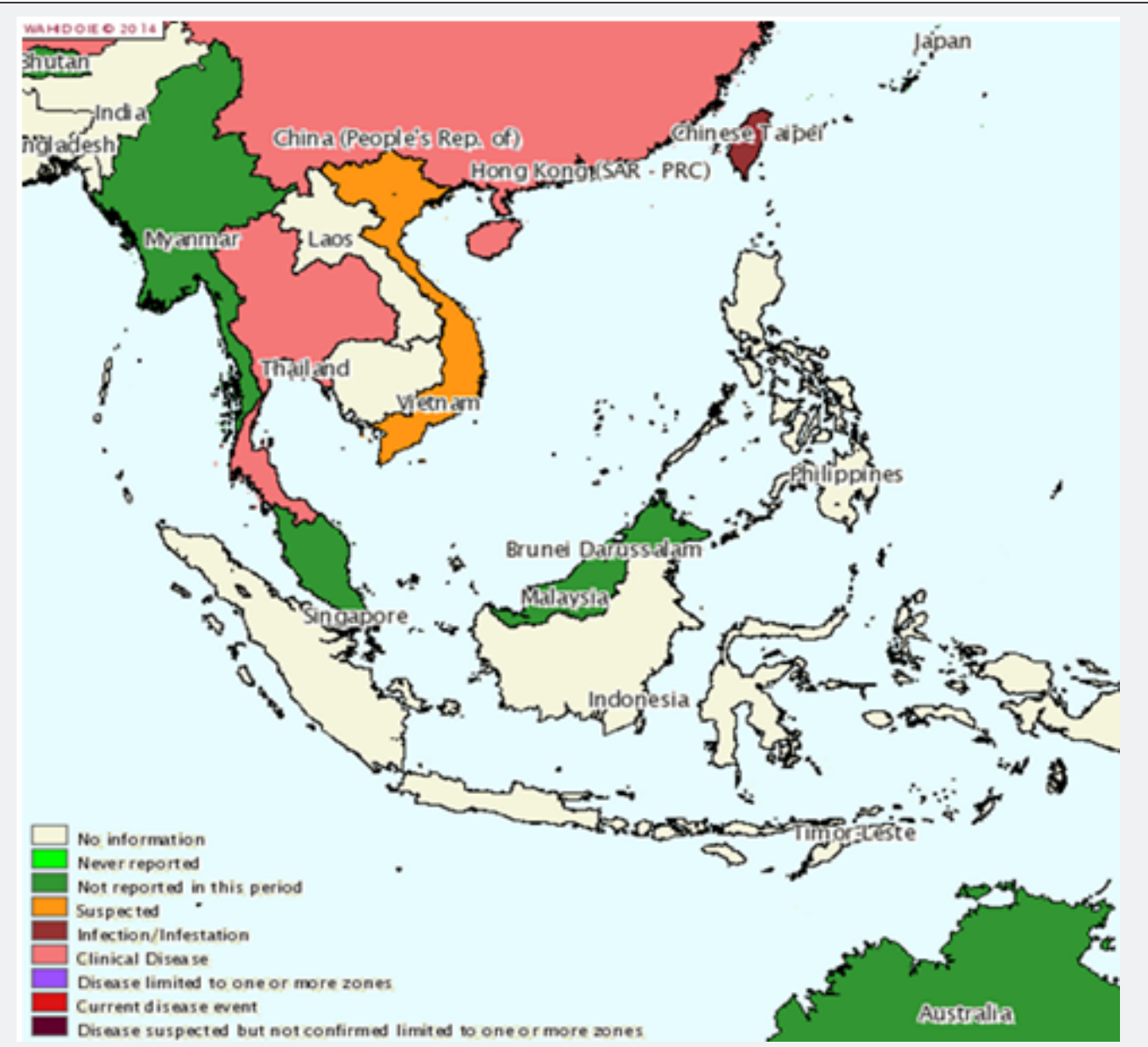

Figure 1: Bovine tuberculosis disease distribution maps for livestock and wildlife until end of 2013 (sourced: WAHID OIE 2013).

Cases of wildlife TB mainly elephant TB has been reported in various countries in SEA. In Thailand (2005-2008), four Asian elephants (Elephas maximus) were confirmed to be infected with $M$. tuberculosis by bacterial isolation and sequencing. This M. tuberculosis may be classified into ancestral and modern strains based on M. tuberculosis-specific deletion TbD1, identical strains of the ancient TbD1-positive and identical strains of $M$. tuberculosis ATCC 27294, the modern type. On the basis of the molecular studies, it was believed that M. tuberculosis was probably transmitted to these elephants from humans [24]. Also a case of captive Malayan tapir (Tapirus indicus) with disseminated tuberculosis confirmed M. tuberculosis by molecular test was reported in 2010 in Thailand. The macroscopic lesions were indicative of disseminated form of TB characterized by multiple abscesses and granulomas with caseous necrotic centre in most of the organs. 
The infection may rise through close prolonged contact with a person or animal with active tuberculosis, and imported animals that were already infected with tuberculosis and develop the disease after being imported [25]. Since Thailand is endemic for tuberculosis [26], the possible disease transmission are either direct contact with the animals by the public or access to contaminated carcasses, animal carriers, or food and water containing the bacteria. In Peninsular Malaysia, studied on the TB seroprevalence of Asian elephant and their handlers were estimated at $20.4 \%$ and $24.8 \%$ respectively. From 151 trunk wash examines, 24 acid-fast organism were isolated, 23 were identified by hsp65-based sequencing as non-tuberculous mycobacteria which are $M$. arupense, $M$. columbines, $M$. intracellular, M. asiaticum, M. mantenii, M. fortuitum, M. gilvum, M. hiberniae and M. kumamotonense. These high seroprevalence in the elephants and their handlers suggests frequent, close contact, two-way transmission between animals and humans within confined workplaces [27].

In non-human primates (NHP) example, one potentially infected macaque in animal research facilities in Thailand was related with a grade 4 reaction of tuberculin test but showed no signs of active disease [28]. The culture samples confirmed the presence of $M$. tuberculosis. This case demonstrated that mycobacterium infections can occur in closed macaque colonies, even with strict assurance measures. Construction activities at the facility may be possibly infected by exposure to either aerosols or sputum from construction personnel. In other findings, buccal swabs collected from macaques representing numerous species in three SEA countries (Thailand, Indonesia and Singapore) included pets, show monkeys free ranging, zoos and monkey temples. DNA was isolated and the PCR amplified IS6110 from 84 (31.9\%) of the macaques.

Based on the known epidemiology of MTC species, $M$. tuberculosis and $M$. bovis are the most likely mycobacterial species to be present in these specimens. M. tuberculosis is endemic in human populations in countries such as Indonesia, Nepal and Thailand, providing wide opportunity for human to NHP transmission. Few published research were available on the interaction of macaques and domestic cattle, though range overlap is not uncommon, giving an opportunity for crossspecies transmission to macaques [29].

\section{Surveillance Systems and Control Measures for TB in SEA}

Based on the reported TB control program in SEA by the WAHID OIE, bovine TB is known to be a notifiable disease for the most countries which deployed a passive surveillance which they were interested in zoonotic disease only when the incidence/prevalence was high or during epidemics. Bovine TB was surveyed in livestock including cattle, buffaloes, goats, sheep, farmed deer and undetermined wildlife species. As with any surveillance system, the fulfilment of information is problematic in SEA [30]. It can be advocated by the number reported TB cases from 2005-2013 where only 4 countries have an incidence of only few cases. Like many TB reported cases in livestock and wildlife in other regions, the likelihood of TB disease cases in SEA are expected to have a similar outcome.

\section{Potential Risks of TB in SEA}

\section{Existence and Widespread of Suids and Cervids TB}

Examples are the Eurasian wild boar and wild cervids such as white tailed-deer, elk, red deer and fallow deer suggested that MTC could survived and maintained in these population. Interestingly, red deer and wild boar share similar molecular type of MTC and about 54\% of MTC antigens spoligotypes similar to human types eventually may cause a public health risk especially to hunters, wildlife personnel and game meat consumers. Existence and widespread of suids and cervids in SEA is an important factor to be considered for active bovine TB disease surveillance. There are 3 subspecies grouping of native wild boar throughout SEA [31], namely 'Indian races' (Sus scrofa cristatus) ranged in Myanmar and Thailand, 'Eastern races' (Sus scrofa moupinensis) in Vietnam and 'Indonesian/banded pig' (Sus scrofa vittatus) ranged from Indonesia to Malaysia. Wild pigs are abundant in many parts of its range in SEA and have been recorded high in some area as tabulated in Table 1.

Table 1: Abundance estimates of wild boar in selected area in Southeast Asia.

\begin{tabular}{|c|c|c|c|c|c|}
\hline Country & Location & Density (N per km²) & Estimates Total Area & Source & Present of Predators \\
\hline Indonesia & $\begin{array}{c}\text { Bukit Barisan } \\
\text { National Park, } \\
\text { Sumatra (1999) }\end{array}$ & $4.5(4.4-6.06)$ & $836 \mathrm{~km}^{2}$ & O'Brien et al. [11] & $\begin{array}{c}\text { Yes }(\mathrm{est} \text {. } 1.2-3.2 \\
\left.\text { tigers } / 100 \mathrm{~km}^{2}\right)\end{array}$ \\
\hline Indonesia & $\begin{array}{c}\text { Peucang island, Ujong } \\
\text { Kulon National Park, } \\
\text { Java }\end{array}$ & $27-32$ & - & Pauwels [65] & No \\
\hline Malaysia & $\begin{array}{c}\text { Merapoh, National } \\
\text { Park; Kuala Trenggan, } \\
\text { National Park; }\end{array}$ & $3.63-4.17$ & $600 \mathrm{~km}^{2}$ & $\begin{array}{c}\text { Kawanishi \& Sunquist } \\
(2004)\end{array}$ & $\begin{array}{c}\text { Yes }(1.10-1.98 \\
\left.\text { tiger } / 100 \mathrm{~km}^{2}\right)\end{array}$ \\
\hline
\end{tabular}


Journal of Dairy \& Veterinary Sciences

\begin{tabular}{|c|c|c|c|c|c|}
\hline Malaysia & $\begin{array}{l}\text { Kuala Koh, Taman } \\
\text { Negara National Park }\end{array}$ & & & & \\
\hline Malaysia & $\begin{array}{c}\text { Pasoh forest reserve } \\
\text { (1998) } \\
\text { Pasoh forest reserve } \\
\text { (1996) }\end{array}$ & $\begin{array}{l}27.0(16.2-44.7) \\
47.0(28.2-78.6)\end{array}$ & $\begin{array}{l}79.9 \mathrm{~km}^{2} \\
81.0 \mathrm{~km}^{2}\end{array}$ & Ickes [62] & $\begin{array}{l}\text { No } \\
\text { No }\end{array}$ \\
\hline Thailand & Huai Kha Khaeng & $<0.5$ & $50 \mathrm{~km}^{2}$ & Srikosamatara & Yes \\
\hline Singapore & $\begin{array}{l}\text { wildlife sanctuary } \\
\text { Singapore Island }\end{array}$ & $34.5(23.6-45.4)$ & - & $\begin{array}{c}\text { Srikosamatara [66] } \\
\text { Yong et al. [67] }\end{array}$ & No \\
\hline Cambodia & $\begin{array}{l}\text { Eastern Plains of } \\
\text { Cambodia and the } \\
\text { Southern Annamite } \\
\text { mountain range } \\
\text { (2010) }\end{array}$ & $2.04(1.19-3.49)$ & $1800 \mathrm{~km}^{2}$ & 0’Kelly et al. [64] & $\begin{array}{c}\text { Yes (est. } 70 \\
\text { tigers } / 1800 \mathrm{~km}^{2} \text { ) }\end{array}$ \\
\hline Cambodia & $\begin{array}{l}\text { Mondulkiri Protected } \\
\text { Forest and Phnom } \\
\text { Prich Wildlife } \\
\text { Sanctuary }\end{array}$ & $1.4(0.9-2.3)$ & $3400 \mathrm{~km}^{2}$ & Gray et al. [60] & $\begin{array}{l}\text { Yes (est. } 0.1 \text { per } \\
\quad 100 \mathrm{~km}^{2} \text { ) }\end{array}$ \\
\hline
\end{tabular}

As for cervids, the species are widespread in their native region. They can be found in a wide range of habitats and geographical landscape from cold to the tropics. In areas where extensive carnivore populations are present and have not been significantly reduced by humans, predation serves as an important reason for mortality in cervids. As in many species, predation is the dominant medium of controlling population densities [32]. Many cervids in SEA are categorized as endangered species including Calamian deer (Axis calamianensis), hog deer (Axis porcinus), Philippines spotted deer (Rusa alfredi) and Eld's deer (Rucervus eldii). Human settlement, agricultural expansion, local hunting for meat, skin, velvet and trophy are the significant threat for the population declining [33-36].

Sambar deer, Timor deer (Rusa timorensis) and Philippines deer are the remaining that are still locally common and under vulnerable status Timmins et al. [36]. Sambar deer have been recorded to have $0.01-0.02 / \mathrm{km}^{2}$ population densities in some national park in Malaysia, widespread population based on $80 \%$ detection by the camera trapping sites in Myanmar, abundant in some wildlife sanctuary in Thailand which estimated at 2-3 individuals $/ \mathrm{km}^{2}$, common spread in Vietnam and Cambodia and is not under major threat in Indonesia [37-39].

Open Air Livestock and Extensive Farming System (Potential Wildlife-Livestock Interface)

SEA is considered an important regional livestock market on swine meat. Available data swine livestock population in SEA for 2012-2013 indicated the population ranged from 792,000$21,700,00$. Although many of countries has moving towards close house system and intensive farming, nevertheless, they are still many farmers operating in their traditional way of open house and extensive livestock management especially in rural area. This would be a major possible way of wildlife-livestock interaction.

\section{Farming Wildlife (Example Of Deer)}

The common species of deer farming among SEA region are Timorensis (Javan) deer. This is the commonest deer since they are smaller than the sambar deer which likewise used as farmed deer. The handling is much less demanding and it can occupy open grasslands, thereby presenting an alternative to diversification in the livestock production industry. Deer farming is rather small in SEA but interest is growing. As presented by WAHIDOIE, accessible information in 2012 demonstrated farmed deer population were 13,136 (Malaysia) and 7,777 (Thailand) and the population are believed to be increased over the year.

\section{Potential Risks of TB Spread Within SEA and to Other Region}

Bovine TB in wildlife is typically viewed as a potential zoonotic disease threat. Indeed, wild animals can and do play as reservoirs of infection and may act a direct health risk to consumers of infected wildlife products. Nonetheless, it is the indirect risk route, by which wildlife reservoirs may affect livestock animals, that is the foundation for concern, because it is the bovine link which poses the greatest risk for human infection. The current concern is that the presence of infection in certain wild maintenance hosts may hamper disease control in livestock. The SEA can be separated into two regions, the islands (consist of the Philippines, Indonesia and part of Malaysia) and the mainland (Figure 2). On the mainland, the movement of livestock between different areas can occur via a wide range 
of routes. Often there is not even a need for roads, and animals can be transported between any two points with little chance of detection by the authorities. Controlling livestock movement in these circumstances poses great challenges [40].

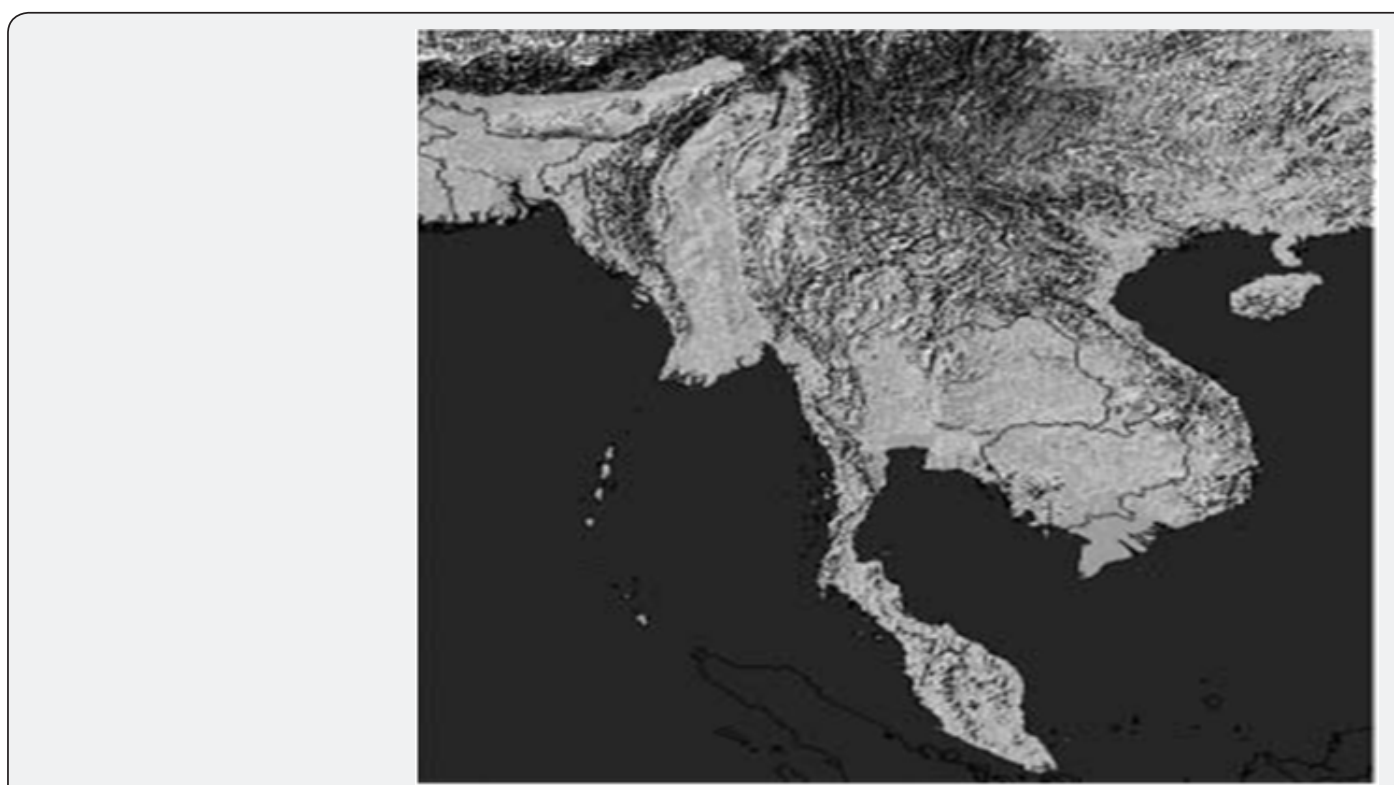

Figure 2: mainland of Southeast Asia Cameron et al. [40].

Another risk factor identified with the emergence of TB disease from wildlife has been the significant increment in consumption of bush-meats in many parts of the world. Consuming a diseased meat by public, zoo animals or prey of wild boar or deer by exotic native species such as tiger, may implicated the conservation issue of exotic species in the future. In 2009 in Malaysia [41], about 4 tons of wild boar meat were seized by the local authorities in the east coast part of Peninsular Malaysia and it was believed illegally hunted and to be smuggling across border. The episodes of illegal meat-seized were continues. Based on series of capture in Malaysia, it has become a significant source of illegally harvested wildlife for the export market to other parts of SEA and East Asia. Within the period 1998-2007, about 35 million animals were trades, 30 million animals of around 300 species being wild-caught which by the SEA members, specifically Malaysia, Vietnam and Indonesia are the significant exporters [42]. In view of reports via ASEAN Wildlife Enforcement Network [43], number of enforcement action recovered for dead animals was increasing over the year, where from 2009 to 2010 alone, a level up from 9,932 to 74,183 dead animals were recovered. This critical estimation of animals seized for illegal market for exportation either for animal trade or meat consumption may help transmitting potential diseases to other region.

\section{Issues and Challenges Faced in Managing Bovine TB in Livestock and Free Ranging Wildlife in SEA}

In developing countries, respondent from local wildlife officials and scientist came out with high assertion that lack of resources or financing and absence of existing government wildlife surveillance are the main issues in wildlife disease surveillance [44]. In addition, insufficient human and laboratory limits as well as poor coordination hampered the surveillance system. They likewise concur that the lack of wildlife surveillance is due to limited interest or awareness regarding wildlife disease. Hence a One Health approach which stressed on coordinated interdisciplinary joint effort is highly recommended to address this issue.

A large portion of the nations in SEA is focusing on selected diseases such foot and mouth disease, brucellosis and haemorrhagic septicaemia control and eradication program in livestock due to its high economic impact. Wildlife disease surveillance is less important and does not exist at all until issue or problem arises such as ecological surveillance of bats due to Nipah outbreak. However in recent year many emerging diseases have arisen from wildlife such as Ebola and Henipah virus and wildlife department have been made aware. Through the current Emerging Pandemic Programme (EPT) under U.S. Agency for International Development (USAID) [45], fund has been created for wildlife surveillances under the component "PREDICT" [45]. Opportunities are now available for many countries to build capacity and participate in wildlife surveillance in the SEA countries.

\section{Potential Action/Surveillance System for Wildlife TB Detection in SEA}

Emerging Pandemic Threats (EPT) program aims to enhance surveillance in potential wildlife hosts so as to address emerging infectious diseases from wildlife by strengthening local, regional and global networks. From their survey, the respondents have indicated the importance of working at key human-animal interfaces, such as the hunting area, markets, wildlife-livestock 
interaction and wildlife in captivity. Other than that, working areas also should be focused on areas where wildlife was butchered, shared water sources, and land utilization change. The determinant of key sites of surveillance is pivotal for the further venture of surveillance system implementation.

Given the challenges of getting samples from wild animals, the convenience or opportunistic sampling remains an effective and essential tool to detect wildlife pathogens in general surveillance. Collaboration and involvement with the wildlife department's program will giving the opportunity to do convenience sampling of wild animals and enhance surveillance programs. Targeted surveillance is a more active approach focused on a particular pathogen in a specified wildlife population which is classified as healthy, but is considered at risk of exposure to this pathogen from an identified source, e.g. screening a wildlife population when positive cases in nearby cattle have been found [46]. A general surveillance on gross pathology for diagnosis of bovine TB in white-tailed deer in north eastern Michigan (USA) has brought about usage of targeted sampling by necropsies and culturing tissues of the white-tailed deer population [47].

Development of zoo-based hospital or wildlife captive centre health and disease information may help to the large scale or national free-living wildlife investigation focal area. In Australia, zoo based wildlife hospital disease surveillance or sentinel surveillance uses a collaborative approach and provides a strong model for a disease surveillance program for free-ranging wildlife that enhances the national capacity for early detection of emerging diseases [48]. This system showed that it had the capacity to capture valuable data on disease in free-ranging wildlife that may generally not have been reported, or was reported earlier than would otherwise have happened. Testing individuals at small setting such as zoo may have a trace back capabilities such as in an outbreak of tuberculosis due to $M$. bovis occurred in pot-bellied pigs (Sus scrofa vittatus), red deer (Cervus elaphus), buffalo (Bison bonasus) and European lynxes (Lynx lynx) [49].

Another important issue of managing wildlife TB is the availability of diagnostic tools, which is frequently constrained to those developed for domestic animals and humans [50]. There are current reviews on diagnostic application in wildlife for the last 5 years as a result of the expanding understanding of particular wildlife species play a role in maintaining the $M$. bovis pathogen [50-53]. In wildlife disease surveillance, an extreme care should be taken to ensure the validity of diagnostic tests utilized to identify pathogens applied to a particular wild animal species and the sensitivity and specificity of the tests used should be incorporated in the analysis and interpretation [54].

\section{Opportunity of Global Networking and Knowledge Transfer}

Under the RESPOND-USAID initiative, SEA One Health University Network (SEAOHUN) has emerged to nurture a capacity building under One Health disciplines to respond to emerging and reemerging infectious and zoonotic diseases. This involves universities network from four countries including Indonesia, Malaysia, Thailand and Vietnam. The mission is to give the preparation by training, education and research capacities of the university network to develop knowledge, skills and attitude of One Health. This would be one platform for the regional scientists, veterinarians and wildlife officials to take up research or surveillance on wildlife diseases. Knowledge of outbreaks originating potentially from wildlife varied by global region suggests that there was a lack of communication across stakeholder groups and that there is a need to bring awareness among stakeholders on wildlife health issues in relation to public health.

Opportunities, for example a growing interest or awareness regarding wildlife disease or surveillance programs, could be used as a starting point to acquire the funding needed to increase both human and laboratory capacity for wildlife pathogen surveillance. Essential tasks that should be taken by the international community include better alliance and coordination of international surveillance systems in industrialized and developing countries, improved reporting systems and sharing of international information, active surveillance by incorporating rural populations and wildlife habitats, training of professionals such as veterinarians and biologists in wildlife health management and foundation of joint multidisciplinary groups ready to intervene when disease occur [55-67].

\section{Conclusion}

Data on tuberculosis and the disease nature are still questionable and lacking in most of the SEA countries. Targeted surveillance system should be applied in order to get a better status of unknown livestock and wildlife diseases particularly for bovine tuberculosis. Knowledge transfer from the global disease surveillance and advances in diagnostic tools in wildlife tuberculosis may be useful for the disease investigation. Determination from unknown to known tuberculosis status in wildlife in this region may help to complete the global maps of bovine TB distribution and will help to understand a potential spread of disease due to further exportation of disease from this region to other region. Increasing global interest in defining wildlife tuberculosis reservoir may help developing countries such as in SEA in terms of collaboration and networking with an expertise under One Health alliance by outsourcing the capabilities of funding, human and laboratory resources and knowledge.

\section{References}

1. Fitzgerald SD, Kaneene JB (2012) Wildlife reservoirs of bovine tuberculosis worldwide: Hosts, pathology, surveillance, and control. Vet Pathol 50(3): 488-499.

2. Corner LAL, Murphy D, Gormley E (2011) Mycobacterium bovis infection in the Eurasian badger (Meles meles): The disease, pathogenesis, epidemiology and control. J Comp Path 144(1): 1-24. 
3. Delahay RJ, de Leeuw ANS, Barlow AM, Clifton-Hadley RS, Cheeseman CL (2002) The status of Mycobacterium bovis infection in UK wild mammals: a review. Vet J 164(2): 90-105.

4. Caley P, Hickling GJ, Cowan PE, Pfeiffer DU (1999) Effects of sustained control of brushtail possums on levels of Mycobacterium bovis infection in cattle and brushtail possum populations from Hohotaka, New Zealand. NZ Vet J 47(4): 133-142.

5. Caley P, Hone J, Cowan PE (2001) The relationship between prevalence of Mycobacterium bovis infection in feral ferrets and possum abundance. NZ Vet J 49(5): 195-200.

6. Coleman JD, Coleman MC, Warburton B (2006) Trends in the incidence of tuberculosis in possums and livestock, associated with differing control intensities applied to possum populations. NZ Vet J 54(2): 5260 .

7. Cooke MM, Jackson R, Coleman JD, Alley MR (1995) Naturally occurring tuberculosis caused by Mycobacterium bovis in brushtail possums (Trichosurus vulpecula): pathology. NZ Vet J 43(7): 315-321.

8. Renwick AR, White PCL, Bengis RG (2007) Bovine tuberculosis in southern African wildlife: a multi-species host-pathogen system. Epid Infect 135(4): 529-540.

9. Michel AL (2002) Implications of tuberculosis in African wildlife and livestock. Ann NY Acad Sc 969: 251-255.

10. Schmitt SM, O’Brien DJ, Bruning-Fann CS, Fitzgerald SD (2002) Bovine tuberculosis Michigan wildlife and livestock. Ann. NY Acad Sc 969: 262268.

11. O’Brien DJ, Schmitt SM, Fitzgerald SD, Berry DE, Hickling GJ (2006) Managing the wildlife reservoir of Mycobactrium bovis: the Michigan, USA, experience. Vet Microb 112(2,4): 313-323.

12. Shury TK, Bergeson D (2011) Lesion distribution and epidemiology of Mycobacterium bovis in elk and white-tailed deer in southwestern Manitoba, Canada. Vet Med Internat p. 11.

13. Vicente J, Höfle U, Garrido JM, Fernández-De-Mera IG, Juste R, et al (2006) Wild boar and red deer display high prevalences of tuberculosislike lesions in Spain. Vet Res 37(1): 107-119.

14. Gortázar C, Torres MJ, Vicente J, Acevedo P, Reglero M, et al. (2008) Bovine tuberculosis in Doñana biosphere reserve: The role of wild ungulates as disease reservoirs in the last Iberian lynx strongholds. PLoS ONE 3(7): e2776.

15. Garcia-Jimenez WL, Benuitez-Medina JM, Fernandez-Llario P, Abecia JA, Sánchez AG, et al. (2013) Comparative pathology of the natural infections by Mycobacterium bovis and Mycobacterium caprae in wild boar (Sus scrofa). Trans Emerg Dis 60(2): 102-109.

16. Naranjo V, Gortázar, C, Vicente J, de la Fuente J (2008) Evidence of the role of European wild boar as a reservoir of Mycobacterium tuberculosis complex. Vet Microb 127(1,2): 1-9.

17. Gortázar C, Vicente J, Samper S, Garrido JM, Fernández-De-Mera IG, et al. (2005) Molecular characterization of Mycobacterium tuberculosis complex isolates from wild ungulates in south-central Spain. Vet Res 36(1): 43-52.

18. Squires D (2013) Biodiversity conservation in Asia. Asia Pacific Pol Stud. 1: 144-159.

19. Sodhi NS, Posa MRC, Lee TM, Bickford D, Koh LP, et al. (2010) The state and conservation of Southeast Asian biodiversity. Biodiv. Conservat. 19(2): 317-328.

20. Nair N, Wares F, Sahu S (2010) Tuberculosis in the WHO South-East Asia Region. Bulletin of the World Health Organization 88: 164-164.

21. Acha PN, Szyfres B (1987) Zoonotic tuberculosis. In: Zoonoses and communicable diseases common to man and animals. Pan American Health Organization/World Health Organization, Washington, USA, Scientific Publication, pp. 503.
22. Abubakar I, Zignol M, Falzon D, Raviglione M, Ditiu L, et al. (2013) Drug-resistant tuberculosis: time for visionary political leadership. Lanc Infect Dis 13(6): 529-539.

23. WAHID (2013) World Animal Health Information Database (WAHID) Interface.

24. Angkawanish T, Wajjwalku W, Sirimalaisuwan A, Mahasawangkul S, Kaewsakhorn T et al. (2010) Mycobacterium tuberculosis infection of domesticated Asian elephants. Thailand, Asia, Emerg Infect Dis 16(12): 1949-1951.

25. Une Y, Mori T (2007) Tuberculosis as a zoonosis from a veterinary perspective. Comp Immuno Microb Infect Dis 30(5,6): 415-425.

26. Palwatwichai A (2001) Tuberculosis in Thailand. Respiratory 6: 65-70.

27. Ong BL, Ngeow YF, Abdul Razak MFA, Yakubu Y, Zakaria Z, et al. (2013) Tuberculosis in captive Asian elephants (Elephas maximus) in Peninsular Malaysia, Epid Infect 141(7): 1481-1487.

28. Payne KS, Novak JJ, Jongsakul K, Imerbsin R, Apisitsaowapa Y, et al. (2011) Mycobacterium tuberculosis infection in a closed colony of rhesus macaques (Macaca mulatta). J Am Assoc Lab Anim Sc 50(1): 105-108.

29. Wilbur AK, Engel G, Rompis A, Putra IGAA, Y-H Lee BPA, et al. (2012) From the mouths of monkeys: Detection of Mycobacterium tuberculosis complex DNA from buccal swabs of synanthropic macaques. Am J Primat 74(7): 676-686.

30. Coker RJ, Hunter BM, Rudge JW, Liverani M, Hanvoravongchai P (2011) Emerging infectious diseases in Southeast Asia: regional challenges to control. Lancet 377(9765): 599-609.

31. Groves CP, Grubb P (1993) The Eurasian suids (Sus and Babyrousa). Taxonomy and description. In: Oliver WLR (Eds.), Pigs, peccaries, and hippos: status survey and conservation action plan. International Union for the Conservation of Nature, Gland, Switzerland, pp. 107-111.

32. Holmes K, Jenkins J, Mahalin P, Berini J (2011) Cervidae (On-line), Animal Diversity Web, USA.

33. Timmins R, Duckworth JW, Samba Kumar N, Anwarul Islam M, Sagar Baral H et al. (2012) Axis porcinus. The IUCN Red List of Threatened Species.

34. Oliver W, MacKinnon J, Ong P, Gonzales JC (2008) Rusa marianna. The IUCN Red List of Threatened Species, UK.

35. Oliver W, Widmann P, Lastica E (2008) Axis calamianensis. The IUCN Red List of Threatened Species, UK

36. Timmins RJ, Duckworth JW (2008) Rucervus eldii. The IUCN Red List of Threatened Species, UK.

37. Timmins RJ, Steinmetz R, Sagar Baral H, Samba Kumar N, Duckworth JW, et al. (2008) Rusa unicolor. The IUCN Red List of Threatened Species, UK.

38. Kawanishi K, Sunquist ME (2004) Conservation status of tigers in a primary rainforest of Peninsular Malaysia. Biol. Conservat. 120(3): 329-344.

39. Lynam AJ (2003) A national tiger action plan for the union of Myanmar. Myanmar Forest Department, Ministry of Forestry, Yangon, Myanmar.

40. Cameron AR, Baldock C, Chamnanpood P (1999) Epidemiology and dynamics of major livestock diseases in Southeast Asia. In: Understanding animal health in Southeast Asia. Advances in the collection, management and use of animal health information. Sharma P, Baldock C (Eds.), ACIAR Monograph 58: 15-31.

41. TRAFFIC (2009) Wildlife Trade News: Wild boar meat seized in Malaysia. Traffic, UK.

42. Nijman V (2010) An overview of international wildlife trade from Southeast Asia. Biodiv. Conservat 19(4): 1101-1114. 
43. Asean-Wen (ASEAN Wildlife Enforcement Network) (2013).

44. Schwind JS, Goldstein T, Thomas K, Mazet JAK, Smith WA (2014) Capacity building efforts and perceptions for wildlife surveillance to detect zoonotic pathogens: comparing stakeholder perspectives. BMC Pub Heal 14: 684 .

45. USAID (2014) United States Agency for International Development, USA.

46. APHIS (2011) Guidelines for surveillance of bovine tuberculosis in wildlife. Animal and Plant Health Inspection Service. P. 58.

47. Schmitt S, Fitzgerald S, Cooley T, Bruning-Fann C, Sullivan L, et al (1997) Bovine tuberculosis in free-ranging white-tailed deer from Michigan. J Wild Dis 33(4): 749-758.

48. Cox-Witton K, Reiss A, Woods R, Grillo V, Baker RT, et al. (2014) Emerging infectious diseases in free-ranging wildlife-Australian zoo based wildlife hospitals contribute to national surveillance. PLoS ONE 9(5): e95127.

49. Schmidbauer S, Wohlsein P, Kirpal G, Beineke A, Müller G, et al. (2007) Outbreak of Mycobacterium bovis infection in a wild animal park. Vet Rec 161(9): 304-307.

50. Maas M, Michel AL, Rutten VP (2013) Facts and dilemmas in diagnosis of tuberculosis in wildlife. Comp Immuno Microb Infect Dis 36(3): 269 825.

51. Chambers MA (2013) Review of the diagnosis of tuberculosis in nonbovid wildlife species using immunological methods-an update of published work since 2009. Trans Emerg Dis 60(1): 14-27.

52. Schiller I, Oesch B, Vordermeier HM, Palmer MV, Harris BN, et al. (2010) Bovine tuberculosis: a review of current and emerging diagnostic techniques in view of their relevance for disease control and eradication. Trans Emerg Dis 57(4): 205-220.

53. Chambers MA (2009) Review of the diagnosis and study of tuberculosis in non-bovine wildlife species using immunological methods. Trans Emerg Dis 56(6,7): 215-227.

54. OIE (2010) Training manual on wildlife diseases and surveillance. World Organization for Animal Health (OIE). p. 46.

55. Chomel BB, Belotto A, Meslin FX (2007) Wildlife, exotic pets, and emerging zoonoses. Emerg. Infect Dis 13: 6-11.

This work is licensed under Creative Commons Attribution 4.0 License DOI: 10.19080/JDVS.2018.06.555683
56. De Lisle GW, Yates GF, Coleman JD (2009) Isolation of Mycobacterium bovis from brushtail possums with non-visible lesions. NZ Vet J 57(4): 221-224.

57. Fitzgerald SD, Kaneene JB, Butler KL, Clarke KR, Fierke JS et al. (2000) Comparison of postmortem techniques for the detection of Mycobacterium bovis in white-tailed deer (Odocoileus virginianus). J Vet Diag Invest 12(4): 322-327.

58. Gallagher J, Clifton-Hadley RS (2000) Tuberculosis in badgers: a review of the disease and its significance for other animals Res Vet Sci 69(3): 203-217.

59. Gavier-Widen D, Chambers MA, Palmer N, Newell DG, Hewinson RG (2001) Pathology of natural Mycobacterium bovis infection in European badgers (Meles meles) and its relationship with bacterial excretion. Vet Rec 148(10): 299-304.

60. Gray TNE, Phan C, Pin C, Prum S (2011) Establishing baseline ungulate densities in Mondulkiri protected forest and Phnom Prich wildlife sanctuary. WWF Report. p. 46.

61. Hedges S, Duckworth JW, Timmins RJ, Semiadi G, Priyono A (2008) Rusa timorensis.

62. Ickes K (2001) Hyper-abundance of native wild pigs (Sus scrofa) in a lowland dipterocarp rain forest of Peninsular Malaysia. Biotropica 33: 682-690.

63. O’Brien TG, Kinnaird MF, Wibisono HT (2003) Crouching tigers hidden prey: Sumatran tiger and prey populations in a tropical forest landscape. Anim Conservat 6(2): 131-139.

64. O’Kelly HJ, Evans TD, Stokes EJ, Clements TJ, Dara A, et al. (2012) Identifying conservation successes, failures and future opportunities; assessing recovery potential of wild ungulates and tigers in Eastern Cambodia. PLoS ONE 7(10): e40482.

65. Pauwels W (1980) Study of Sus scrofa vittatus, its ecology and behavior in Ujung Kulon nature reserve, Java, Indonesia. PhD dissertation, University of Basel, Switzerland,Europe pp. 100.

66. Srikosamatara S (1993) Density and biomass of large herbivores and other mammals in a dry tropical forest, western Thailand. J Trop Eco 9(1): 33-43.

67. Yong DL, Y-H Lee BP, Ang A, Tan KH (2010) The status on Singapore Island of the Eurasian wild pig Sus scrofa (mammalia: suidae). Nat Singapore 3: 227-237

\section{Your next submission with Juniper Publishers will reach you the below assets}

- Quality Editorial service

- Swift Peer Review

- Reprints availability

- E-prints Service

- Manuscript Podcast for convenient understanding

- Global attainment for your research

- Manuscript accessibility in different formats

( Pdf, E-pub, Full Text, Audio)

- Unceasing customer service

Track the below URL for one-step submission https://juniperpublishers.com/online-submission.php 